\title{
Environmental management and hotel profitability: operating performance matters
}

\section{Gestão ambiental e rentabilidade hoteleira: questões de desempenho operacional}

\author{
Alp Yenidogan \\ Faculty of Economics and Administrative Sciences, Akdeniz University, Antalya, Turkey, alp.yenidogan@kamelyacollection.com
}

Tugba Gurcaylilar-Yenidogan

Faculty of Economics and Administrative Sciences, Akdeniz University, Antalya, Turkey, gurcaylilar@akdeniz.edu.tr

\section{Nilufer Tetik}

Faculty of Tourism, Akdeniz University, Antalya, Turkey, niltetik@akdeniz.edu.tr

Received: 17.12.2020; Revisions required: 05.03.2021; Accepted: 12.07.2021

\begin{abstract}
While there is growing consensus on the benefits of going green, the relative benefits of revenue-enhancing and cost-cutting effects of environmental practices over performance have remained a more conservative and less explored phenomenon in corporate management studies. The present study investigates the two parallel mediation effects of cost-saving and revenue generation on profitability through environmental management practices. A bootstrap method is employed to make a statistical inference of the causal mediation effects. The data collected from the lodging industry in Antalya/Turkey revealed that the revenue-enhancing and cost-cutting effects of environmental participation have a positive impact on profitability, while no difference was identified in the strength of the indirect effects. In conclusion, the findings of this study indicate a complementary effect of cost reduction and revenue enhancement for green profit.
\end{abstract}

Keywords: Environmental management practices, cost savings, revenue enhancement, profitability, accounting information, lodging industry.

\section{Introduction}

Like all sectors in the global economy, tourism and hospitality need now more than ever to be managed in an environmental and sustainable way. While complementary tourism assets (hotels, restaurants, theme parks, etc.) contribute to the increasing attractiveness of tourist destinations and ensure accelerated growth of revenues in tourism, while tourism facilities consume a significant amount of primary tourism assets, and in most situations, the concretization of green spaces leads to the irreversible destruction of habitat (ClaverCortés et al., 2007; De Grosbois, 2012; Hillery et al., 2001). The benefits linked to improved infrastructure and facilities are often at the expense of the natural environment, and this situation creates a tourism paradox in which the expansion of tourism business causes simultaneous destruction of precious landscape over time, shifting tourism demand towards alternative destinations and substitute facilities. This tourismenvironment struggle has led to the universal growth of sustainable tourism activities (Rodríguez \& Cruz, 2007). The rapid diffusion of environmental responsibility has increasingly transformed tourism organizations' business processes and operations toward environmentally sensitive practices.

\section{Resumo}

Embora exista um consenso crescente sobre os benefícios ambientais, os benefícios relativos dos efeitos do aumento de receita e redução de custos das práticas ambientais sobre o desempenho permaneceram um fenómeno mais conservador e menos explorado nos estudos de gestão corporativa. O presente estudo investiga os dois efeitos paralelos de mediação de economia de custos e geração de receita sobre os resultados através de práticas de gestão ambiental. Um método bootstrap é utilizado para fazer uma inferência estatística dos efeitos da mediação causal. Os dados obtidos do setor de alojamento em Antalya/Turquia revelaram que os efeitos do aumento de receita e redução de custos da participação ambiental têm um impacto positivo no lucro das empresas, enquanto nenhuma diferença foi identificada na intensidade dos efeitos indiretos. Em conclusão, os resultados deste estudo indicam um efeito complementar de redução de custos e aumento de receita relativamente ao lucro verde.

Palavras-chave: Práticas de gestão ambiental, redução de custos, aumento de receita, lucro, informação contabilística, setor do alojamento.

Nowadays, many tourism businesses are publicly announcing their intention to act responsibly for the benefit of the planet and its people (Stylos \& Vassiliadis, 2015). For example, TUI, the world's largest tourism company, has adopted the motto Better Holidays and a Better World, implementing a policy to work with environmentally friendly hotels that make sustainable innovations (TUI Group, 2019), compelling hotels to engage in more environmentally responsible behavior to ensure the continuation of their partner accreditation.

Undoubtedly sustainability management has a strong influence on financial business performance (Mihalič, 2016; Stoddard et al., 2006), although corporate sustainability remains as a more conservative and less explored phenomenon in tourism studies (Dwyer, 2005; Lucas \& Wilson, 2008; Mihalič, 2013; Stylos \& Vassiliadis, 2015). More specifically, the economic impact of environmental practices in tourism business operations was largely overlooked until two decades ago (López-Gamero et al., 2009). More important than the small number of studies into the issue of green tourism is that all the studies produce conflicting and insufficient results and fail to establish a link between environmental practices and financial performance. To 
exemplify this point, we provide a summary of previous studies in three categories.

The first category comprises studies dealing with performance and managerial practices aimed at sustainability as separate but interrelated concepts. Notable among these are Bramwell and Alletorp (2001) and Kasim (2009), examining managerial attitudes towards environmental concerns; Alshehhi et al. (2018) and Trung and Kumar (2005), focusing on potential energy savings, and investigating the use of energy-efficient equipment; Le et al. (2006) and Mensah (2006), investigating the adoption process for and the degree of implementation of environmental management practices; and De Grosbois (2012), Jones et al. (2014), Mihalič et al. (2012), and Stylos and Vassiliadis (2015), exploring differences in the perceived importance of sustainability practices. All in all, the economic pillar was found to be of primary importance in sustainability performance. In the second category, Cvelbar and Dwyer (2013), and Levy and Park (2011) make importance-performance analyses with a view to understanding which sustainability practices need to be improved to ensure better performance, while Bohdanowicz (2006), and Levy \& Park (2006) report that operational cost savings provide the strongest incentive for sustainable behaviors. The third and the last category comprises the remaining studies investigating the causal relevance of environmental management to hotel performance, although academic studies into the causal explanation of green profit, including those by Assaf et al. (2012), Inoue and Lee (2011), Pereira-Moliner et al. (2015) and Rodríguez and Cruz (2007), tended to remain inconclusive, and sometimes contradictory. Carmona-Moreno et al. (2004) identified a nonsignificant relationship between environmental practice and hotel performance (in terms of operating income and occupancy rate). Similarly, Inoue and Lee (2011) reported on the statistically insignificant association between the environmental pillar and profitability.

In contrast, Assaf et al. (2012) identified a positive influence of the extent of environmental reporting on hotel performance. Beyond that, Cerchione and Bansal (2020), Kang et al. (2010), and Rodríguez and Cruz (2007) found a significant positive relationship between the responsible behavior of hotels and financial asset performance. On the non-financial side, Ghaderi et al. (2019) reported a direct positive link between responsible behavior and corporate reputation, while Kassinis and Soteriou (2003) described the revenue-increasing effects of green customer loyalty. On the other side, the studies by Alvarez-Gil et al. (2001), Garay and Font (2012), Gil et al. (2001), and SegarraOña et al. (2012) found that environmental practices had a positive effect on short-term financial performance. Moving away from the direct effects of environmental practices on hotel performance, the findings from the study by Zhang et al. (2012) confirmed the financial performance-enhancing effect of environmental performance.

Similarly, Claver-Cortés et al. (2007) found that environmental proactivity does not lead to a meaningful relationship with profitability but does exert a significant and positive influence on operating performance (e.g., occupancy rate). Bagur-Femenias et al. (2015), López-Gamero et al. (2009), and Pereira-Moliner et al. (2015) further support the indirect causality effect of environmental management on financial performance, adopting a co-evolutionary perspective to examine the impact of corporate sustainability practices on financial performance. This perspective argues that hotels with better environmental performance can improve financial performance through lower costs and/or differentiation in gaining a competitive advantage. It can be seen that environmental management does not necessarily have a direct positive effect on financial performance, and may sometimes even undermine short-term profitability.

Despite the above-mentioned studies that pay primary attention to the economic dimension of corporate sustainability in the lodging industry, there has been no study to date examining specifically the aggregate impact of environmental participation. Indeed, the cost and revenue-generating benefits of environmental participation are yet to be understood in terms of their precise contribution to profit. Previous literature has also failed to consider the causal mediation effects of return and operating performance on the relationship between environmental management practices and profitability, which leads to biased estimations.

While some studies support green profitability, others reveal a neutral performance effect of going green in the lodging industry and even highlight some negative effects of environmental stimuli on financial performance within a wide spectrum of the sustainability literature. The present study aims to disentangle the role of environmental management in profitability, for which we analyze the effects of operating costs and operating revenues as multiple mediators within the environmental sustainability model. The study goes on to investigate the comparative impacts of service operating performance. The profitability-enhancing effect of a hotel's environmental activities depends on efficient green management, keeping costs low, and generating revenues. Overall, the study presented here reveals the equal importance of developing energy-saving strategies and revenue streams to enhance hotel profitability. This finding, however, is limited to the Turkish context, which is in the early stages of proactive sustainable hotel practice. The cost-minimizing and revenueincreasing aspects of green operations are likely to have different effect sizes in different cultural contexts. This study may be considered less comprehensive in the scope of cultural geography. Still, despite its narrow area of research, it succeeds in untangling the environmentalism-profitability puzzle by comparing the relative strengths of operating performance centers to reveal the clear-crystallized performance implications of environmental management.

In a nutshell, all of the benefits of management with environmental practices ultimately affect profitability by increasing revenues and decreasing costs. Today's contemporary environmental management approach stands on a widespread convergence of accounting information with value relevance. Thus, recent studies (Hassel et al., 2005; Middleton, 2015; 
Miralles-Quirós, 2018; Singal, 2014) have demonstrated that the risk/return performance of environmentalism gels well with profitability in the long run, and this finding can be extended to the short term with more consistent results. To this end, the present study examines the multiple mediation effects of service operating performance and thus contributes to green management literature in a hospitality context.

The rest of this paper is organized as follows. Section two presents a theoretical discussion of the economic impacts of environmental activities. Section three describes the methodology applied to estimate the corporate profitability that can be expected from environmental practices, based on findings from the Turkish lodging industry. Section four presents the results of descriptive statistical and multiple mediation analyses. Section five concludes the paper by providing some potential implications.

\section{Theoretical discussion}

The economic impacts of environmental activities have become increasingly apparent in recent years. Since 1998, only 100 companies worldwide have accounted for 71 percent of the total greenhouse gas emissions (Climate Accountability Institute, 2017), and this situation is unsustainable as a onesided self-reflection of the capitalist society. The faster the global climate warms, the greater the financial risk from environmental hazards given the reflexive nature of the planet. However, it is still difficult to keep the environmental sustainability focus alive in organizations (Gimenez et al., 2012). Since sustainability objectives tend to be systematically overlooked, corporate scandals have led to the crumbling of many successful businesses and even non-resilient economies, leading public expectations of transparency to steadily increase (Manderson, 2006). As a result, accountability is no longer a sole concern for regulatory requirements (Donleavy, 2010). Beyond the financial aspect, accountability is closely related to corporate actions and decisions.

Sustainability accounting (Elkington, 1998) helps disclose environmental information transparently to all stakeholders (Freeman et al., 2010). The stakeholder approach to accounting treats financial performance as the first-order consequence of corporate actions. When environmental practices serve disaggregated centers (costs, revenue, assets/investments) for performance portfolios in different financial periods (long- or short-term), profitability tends to move in the opposite direction. A wide range of theoretical grounds have been put forward linking profitability to stakeholder behavior. Yet, previous studies addressing the profit-environment nexus have focused firmly on the "cost" versus "value" paradigms. Looking through the practice-based lens of corporate environmental strategy, discrete paradigms do not lead to a contradictory conclusion but rather employ different logical reasoning when attempting to understand organizational behavior toward environmental practices, and all the different reasons act together in the long-term profitability relationship.
Consequently, allegedly conflicting empirical evidence arises out of tradeoff zones in which the financial benefits of environmental management are weighted against their costs (Walley \& Whitehead, 1994).

Undoubtedly, the question "does it pay to be green?" pioneered an interesting debate on the relationship between environmental management and profitability and has led to a considerable number of studies being conducted to examine the relevance of environmental management to profitability, as detailed in the introductory part. In the first generation of debates on the attainment of green profit without reconciliation findings, sustainability research was divided into two major schools of thought (Hassel, Nilsson \& Nyquist, 2005). The cost-concerned school of environmental management is based on external stakeholders' perceptions of firm value. This stream of thought relies on estimations of future growth prospects by comparing the market values of equity or stock prices. Returns from investments into intangible assets or reputation were found to be negative in the short term, and so it was concluded that environmental investments consistently come at a considerable financial cost to the firm. Broadly, environmental engagement from the cost-generating perspective results in capital asset investments at the expense of shareholder interests. Forecasting returns from equity share investments requires a more forward-looking approach to be taken. Previous studies into the additional costs of environmentalism have shown that firms are reluctant to pay more to be green.

Accounting-based measures consider cost savings and revenue generation in the calculation of profit margins. In such approaches, the positive relationship between environmental practices and short-term profitability has received strong support from the value creation school of environmental management. Despite the mixed evidence of the relationship between environmental activities and profitability, discrete schools of thought in environmental management are not necessarily contradictory. Environmentally responsible behavior can improve a firm's financial value in many ways: by enhancing its credibility in the eyes of financial institutions; by ensuring compliance with the relevant regulations; by securing a green brand positioning, and forming a connection with customers; and by reducing costs through the increased efficiency of internal operations. For this reason, the financial relevance of the two main environmental streams complements each other. Value creation (/sales revenues) and cost generation (/capital investments) are thus two sides of the same coin. Accordingly, in the second generation research area, authors (Albertini, 2013; Dixon-Fowler, Slater, Johnson, Ellstrand \& Romi, 2013; Endrikat, Guenther, \& Hoppe, 2014) investigate the various contingency factors (e.g., legal regulations, ownership structure, and board interdependence) that affect the environmentalism-profitability link.

This new stream moved researchers away from the inconclusive attempts to reconcile the different effects of environmental 
engagement and encouraged them to ask the question: when does it pay to be green? This approach revealed the inconclusive or contradictory findings in the first generation of studies to be due mainly to measurement heterogeneity (e.g., reactive versus proactive activities in environmental management and short-term vs. long-term period in financial performance). Distinguishing between reactive and proactive solutions for evaluating environmental performance built a strong hypothetical basis of performance differentiation for environmental activities (Frondel, Horbach \& Rennings, 2007; Nawrocka \& Parker, 2009).

The reactive environmental strategies applied in managerial practice include end-of-pipe investments after pollution has been generated and are based predominantly on regulatory compliance. On the other side, proactive environmental orientation requires preventive action rather than ex-post sanctions. Whereas reactive behaviors are related to the cost of environmental management, proactive behaviors relate to the value relevance. Reactive environmental management may create short-term returns, but proactivity necessitates longer periods to pay off the investment. Consistent with the differential environmental strategies, the studies in the third and last generation (Semenova, Hassel \& Nilsson, 2010; Middleton, 2015; Miralles-Quirós, Miralles-Quirós \& Valente Gonçalves, 2018; Singal, 2014) have examined long-term market performance, and thus support the value relevance of environmental investments. It would seem that this ultimate effort could lead to consensus on whether to go green or not. Environmental engagement is no longer considered a valid approach to the mitigation of uncompensated environmental impacts but instead looks to the development of organizational capabilities to create ecological differentiation.

Given the above, what questions remain to be investigated? Although previous studies have yielded consistent results related to value relevance, there is a promising field of environmental sustainability research that can address multiple mediator effects to achieve better financial performance. Hence, in what ways, and to what extent, does environmentally responsible behavior lead to improved financial performance, enabling organizations to take decisions in accordance with different values at various impact velocities.

\subsection{Cost-concern paradigm of environmental management}

The cost-concern paradigm in environmental management focuses on the expense of green investments. Sustainable environmental management demands the utilization of significant additional resources for the reconfiguration of the existing service production system (Fotiadis et al., 2013). When the costs of environmental investments exceed the potential future returns, the resulting net present value will be negative. In this case, significant green expense deductions undermine the profit bottom. The investmentcentered paradigm draws upon agency- and institutional-theory reasoning to explain the association between financial performance and corporate environmental behavior.
Institutional-theory reasoning in environmental behavior: Environmentalism does not always exist as an intended behavior, being sometimes a stimulus-driven action imposed by a legitimate authority. The unintended but realized nature of organizational actions acts against the principles of the voluntary disclosure of environmental information, and at this point, supreme coercive control is exercised over sustainable environmental actions. Environmental deterioration is subject to legal enforcement, and regulatory sanctions may be applied for breaches of a desired sustainable behavior. In addition to the regulatory acceptance of environmental behavior, mimetic isomorphism will likely occur when environmental practices converge with each other in an organizational population. As a result, environmental conservation practices tend to be applied ceremonially. Under such circumstances, reactive collective action cannot generally be considered an efficient solution for an individual organization, as the cost of investments into environmental matters will likely undermine competitiveness and profitability (Walley \& Whitehead, 1994).

Agency-theory reasoning to environmental behavior: From the agency theory perspective, green capital investments are subject to forward-looking financial risk assessments. Environmentally responsible behaviors are commonly employed for legitimacy, although the green bonds (or debt securities) used to finance investments in green projects tend to perform poorly and undermine the economic bottom line in the early phases (Klassen \& McLaughlin, 1996). Accordingly, organizations encounter considerable reluctance among their investors to pay for environmental engagement. Such skepticism among investors discourages the announcement of environmental initiatives due to the lack of any notable market reaction (Albertini, 2013; Cordeiro \& Sarkis, 1997; Hart \& Ahuja, 1996; Gilley et al., 2000). From the risk management perspective, the securities market tends to punish the top performers in environmental sustainability (Albertini, 2013; Dascalu et al., 2010). Green investing thus creates a win-lose position within the payoff structure. Asymmetric value appropriation in the payoff structure implies simply transferring environmental responsibility and the associated costs to private companies. Hence, agencies consider engagement in managerial practices related to environmental sustainability to be a matter of self-sacrifice for the sake of societal benefit (Inoue \& Lee, 2011).

The cost-concern perspective of environmental behaviors, in short, attributes poor performance to reactive corporate environmental practices and the negative returns on green investments to adverse selections (Nawrocka \& Parker, 2019; Wood \& Jones, 1995). From this perspective, positive returns from alternative projects may be sacrificed to the overwhelming goals of powerful actors (Tufano, 1998). Organizations suffer severe losses from weak corporate governance in which isomorphic adaptation increases the inefficient allocation of resources (Hirth \& Uhrig-Homburg, 2010). Hence, environmental governance within the private 
sector does little more than internalizing the external costs of environmental pollution.

\subsection{Value-creation paradigm of environmental management}

The negative risk-return tradeoff for green securities underestimates the interaction between the natural environment and organizational continuity (Lomborg, 2003). The question of whether environmental management really pays more (Hart \& Ahuja, 1996) should not be reduced to a discussion of the benefits of value creation over risk reduction when making investment decisions related to alternative assets. Neoclassical environmental economics (Friedman, 2007) has been heavily criticized for overemphasizing inefficient investments in green assets and highlighting the negative returns of institutional legitimacy. Green investments are not merely risk mitigation efforts aimed at the prevention of ecological distortion, as environmentally friendly activities are and inherent part of strategic differentiation. In such situations, resource-based views are at the theoretical core of environmental value generation efforts and are in contrast with financial risk assessments of green mutual funds and appeals to operating income when explaining the profitability enhancing impacts of environmental practices.

Legitimacy theory reasoning of environmental behavior: Sustainability management necessitates adopting a business strategy that promotes the survival and success of firms through stakeholder satisfaction. Behind such a strategy is sustainable practices that yield corporate value (Salzmann et al., 2005). It is assumed that companies with high sustainability standards are less detrimental to the environment and society (Child et al., 1999). Environmental behaviors reduce the systemic risks and negative externalities arising from greenhouse gas emissions and/or unethical earnings. Thus, companies with lower exposure to sustainability risks can achieve greater financial performance. Depending on the sustainability risk-reducing impact of environmental management, the successful attainment of responsibility goals increases corporate reputation as a component of intangible assets (Deephouse \& Carter, 2005). Corporate reputation is a valuable information source for customers and other stakeholders, such as investors and creditors, alike. If a company experiences environmental deterioration and thereby gains a bad reputation, this leads to a decrease in the customer base and an increase in customer complaints and lawsuits, and consequently, the sale of stocks held by shareholders (Mishra \& Suar, 2010). Conversely, a firm can gain legitimacy by protecting public interest, thus maintaining social legitimacy, which in turn leads to a good corporate reputation and long-term financial performance. Accordingly, legitimacy can be considered the underlying rationale or the dominant motivation for sustainability reporting. Legitimacy theory has emerged as a natural reaction to institutional pressures and stringent environmental regulations, and unlike the reasoning behind the institutional theory, elucidates the desired outcomes of environmental management practices.
Natural resource-based view reasoning to environmental behavior: Rather than the risk-return tradeoff in green investment decisions, strategic management attributes the value rationality of environmental orientations to competitiveness and economic performance. From a value generation perspective, profit margins are based on the operational value of environmental management practices. Cost savings and revenue generation are considered the operational parameters from which green profits can be calculated. The cost-cutting and revenue growth metrics of accounting permit more certain and immediate success through operational improvement. From the natural resourcebased perspective (Hart, 1995; Hart \& Dowell, 2011), proactive environmental management based on the development of green dynamic capabilities has emerged as a new way of outperforming one's rivals. Systematic environmental disclosures enhance corporate reputation through environmental product differentiation (Branco, 2006; Toms, 2002). Corporate environmental reputation can increase revenue stream, as consumers pay more for products augmented with environmentally responsible management practices. As an alternative environmental strategy, the improvement of management systems through processoriented environmental practices leads to potential cost savings. Consequently, no matter what environmental strategy (cost savings or/and revenue generation) is applied, a win-win situation is created that promises sustained superior financial performance (Porter \& Van der Linde, 1995). Taking a natural resource-based perspective, the present study examines the complement-mediated operating performance effect of environmental management practices on enhancing profitability. Thus, we derive the following hypotheses:

$\mathbf{H}_{1}$ : Operating costs mediate the effect of environmental practices on profitability. (Cost savings effect of environmental management practices)

$\mathbf{H}_{2}$ : Operating revenues mediate the effect of environmental practices on profitability. (Revenue-generating effect of environmental management practices)

$\mathbf{H}_{3}$ : Operating costs and operating revenues have a complementary role in mediating the effect of environmental practices on profitability. (Complement-mediated operating performance effect of environmental practices)

$\mathbf{H}_{4}$ : The mediating role of operating costs (/operating revenues) is stronger than operating revenues (/operating costs) in the relationship between environmental practices and profitability. (Comparative mediation effect of operating performance)

\section{Research Methodology}

\subsection{Problem setting}

There have been many studies to date investigating the performance implications of environmental management practices in the lodging industry, although a lack of consensus still remains on whether the strong adoption of environmental 
management approaches leads to better financial performance. Sector-specific findings indicate that the careful inclusion of possible indirect effects may relieve the tension between environmental management and performance. The expected positive effect in the mentioned link can be expected to have both short- and long-term benefits.

The positive implications of environmental management over financial performance are more apparent when firms take advantage of improved efficiency, increased market share and product quality, better organizational reputation, more satisfied consumers, and many other factors. Despite its wide variety of performance benefits, environmental management affects mainly financial results through increased revenues and lower costs. Consistent with the case of indirect causation, the present study aims to expand upon current literature by examining the multiple mediating effects of service operating performance. To this end, the total, direct, and indirect causal effects of environmental management practices are defined and compared with the estimated effect sizes to yield more conclusive findings. Accordingly, this study hopes to make an additive contribution to the strategy-environmentperformance appraisal.

\subsection{Study design}

We conducted a cross-sectional survey to determine the multiple mediator effects of operating costs and revenues on the relationship between environmental practice and financial performance in the lodging industry. The research was carried out in Antalya, Turkey - one of the world's most popular tourist destinations, with a $600 \mathrm{~km}$ coastline and wide sandy beaches and a very convenient location for an investigation of hoteliers' environmental management practices. The city welcomes 14 million tourists annually (Republic of Turkey Ministry of Culture and Tourism, 2019), although the accelerated growth of tourism infrastructure is threatening to overwhelm the city's ecosystem. This has compelled the Turkish Ministry of Culture and Tourism to look at ways of resolving environmental problems in close cooperation with local governments and infrastructure users.

The research population of this study is the total 391 five-star hotels operating in the different tourism regions of Antalya (Republic of Turkey Ministry of Culture and Tourism, 2017). Hotels with lower star ratings were excluded from the research population due to their limited capacity for investment in sustainable business practices. Antalya airport is the hub of tourist arrivals, and splits the tourist destinations in half along the city, separating the eastern part from the western part. 102 of the five-star hotels in the research population are located in the west of the city, while the remaining 289 hotels are in the east, and so a proportionate stratified sampling approach was adopted to control for possible regional differences. To begin with, the sample size of the study was calculated as 194 hotels at a 95 percent confidence level. After having divided the research population up into the proportional allocations, the sample comprised 51 hotels in the western region and 143 hotels in the eastern region.

Telephone interviews were conducted in the initial round of the data collection process, during which the interest groups of the survey were informed about the research intention. Upon receipt of approval for the participation, primary data was gathered through face-to-face interviews. Despite stating an intention to participate, a considerable number of hotels failed to provide approval for the interview. In addition, the questions were handled consistently by almost one-fifth of the respondents. The collected questionnaires were edited to eliminate inconsistencies, and thereby non-transparent data were extracted from the records. The survey was completed between June 2019 and August 2019, and 91 valid questionnaires (27 from the western part and 64 from the eastern part) were obtained, representing an effective response rate of approximately 23 percent. Hence, the survey was calculated to have a margin of error of +4 percent at a 95 percent confidence level.

\subsection{Multiple mediation analysis}

The Ordinary Least Square (OLS) approach to the estimation of regression parameters requires a significance test to identify the existence of a mediation effect. The Sobel test is widely used for the calculation of the statistical significance of indirect effects, relying on the assumption that indirect effects are normally distributed (Hayes, 2009). Such a normal theory-based inference fails in practical experiments involving small to moderate sample sizes, which in turn increases the vulnerability of statistically significant tests to type-I errors. Hayes (Hayes, 2017) recommends calculating bootstrap confidence intervals to gain an unbiased estimator of the total variance for mediation. The bootstrapping confidence interval method allows for the control of type-l errors and produces better results, even when there is a nonnormal distribution in the sample data (Dastgeer et al., 2020). Following the recommendation of Hayes, in this study of a relatively small sample of hotels, the authors applied the bootstrapping method in SPSS + PROCESS to test multiple mediation hypotheses. The predicted mediators have no causal influence on one another in the present study. Hence, a parallel multiple mediator model was applied to disaggregate the bivariate associations of environmental management practices and financial performance through the two mediating variables of cost-savings and revenue generation.

As a result, the variable environmental practices was modeled to influence financial performance indirectly through mediator variables. The direct effect of $X$ (environmental practices) on $Y$ (financial performance) was estimated with $c^{\prime}$ in equation 2 . This effect displays the effect of $X$ on $Y$ that does not operate through mediators ( $M_{1}$ - operating costs, $M_{2}$ - operating revenues). The indirect effects of $X$ on $Y$ were estimated as the sum of the effect of $X$ on $M_{i}$ (in equation 1) and the effect of $M_{i}$ on $Y$ controlling for $X$ (in equation 2). The confidence intervals (Cl) for the indirect effects provide a statistical indication of whether the $a_{i} b_{i}$ product as a 
whole, rather than its individual components, differs significantly from zero.

In equation 3 , the total effect of environmental practices on financial performance was estimated with $c$, being the SUM of the direct and indirect effects. The equations can be represented in statistical forms as follows:

$$
\begin{aligned}
& M_{i}=i_{M_{i}}+a_{M_{i}}+e_{M_{i}} \\
& Y=i_{Y}+\sum_{i=1}^{k} b_{i} M_{i}+c^{\prime} X+e_{Y} \\
& c=c^{\prime}+\sum_{i=1}^{k} a_{i} b_{i}
\end{aligned}
$$

\subsection{Measures}

The present study makes use of accounting-based performance measures to examine the effect of environmental practices on firm performance. Firm performance in accounting literature is quantified from financial statements such as balance sheet and income statement (Fauzi et al., 2010). The bottom line of an income statement represents the value realized in terms of net profit. Meanwhile, EBITDA is one of the most commonly used profitability ratios for the measurement of the ability of a business to generate income. The term equation comes from the hotel's income statement (Helfert, 2003), and this metric displays the earnings before interest, taxes, depreciation and amortization. While net profit refers to what is left after a firm deducts all expenses from its income, EBITDA serves as a cash proxy that eliminates the effects of possible management manipulation, and is thus adopted in the present study to avoid the distortion of results arising out of the hoteliers' accounting, financing and political decisions. To evaluate profitability of hotels, the dependent variable, $Y$, was operationalized as the log of EBITDA.

Besides EBITDA, the cost-to-income ratio ( $C / I$ ratio) and revenue per available room (RevPAR), $M_{1}$ and $M_{2}$, were used to measure the indirect effects in the relationship between environmental practices and hotel profitability. The cost-toincome ratio ( $\mathrm{C} / \mathrm{I}$ ratio) indicates just how efficiently a hotel is operated, with the lower the $\mathrm{C} / \mathrm{I}$ ratio, the higher the hotel profitability due to cost advantages. Prior to the statistical analysis, a logit transformation was applied to the cost-toincome data (displayed in percentages) for linearizing the sigmoid distributions of proportions (Armitage \& Berry, 1994). On the other hand, RevPAR was calculated by multiplying the average daily rate (ADR) by occupancy rate, and this measure was then used to evaluate hotel effectiveness based on the revenues from operations. While the hotel ADR metric indicates the average price paid per room, this indicator is assessed by the respondents considering the average room price in recent years, excluding the crisis years. The occupancy rate refers to the percentage of the available rooms occupied in recent years, excluding the crisis years. Accordingly, the RevPAR figure is an indicator of the relationship between price and occupancy rate and can be used to evaluate how hotels are performing in terms of revenues. Prior to the analysis, the log transformation was used to normalize the continuous RevPAR data.

The independent variable in this study, $X$, refers to the extent to which the hotels apply environmental practices. In order to appreciate the range of sustainable environmental management applications by hotels, environmental practices with a more proactive approach were listed first, based on the sustainable environmental indicators of ETIS (European Tourism Indicator System), SASB (Sustainability Accounting Standards Board), DVFA (Deutsche Vereinigung für Finanzanalyse und Asset Management), ESG (Environmental, Social, and Corporate Governance) and FEE (Federation of European Accountants). An index was then created to account for the coverage of environmental applications in the lodging industry. The environmental application scale is an index-based approach that is composed of 14 items, each of which corresponds to one particular yes/no question (see appendix) the higher the index, the greater the degree of hotel participation in environmental management practices.

\section{Results}

\subsection{External validity and robustness of sampling}

An Independent-samples T-test was used to compare the environmental orientation of the smaller groups in the population. The results $(t=0.369 ; p>0.05)$ revealed that regardless of the distance, the implementation of environmental management is still similar, with no local difference identified in environmental practices. Such a comparison provides evidence of external validity, indicating that similar results may be obtained from different participant populations (Whitley \& Kite, 2013). In addition to this, the RevPAR data of the hotels that completed the survey were compared with their STR performance statistics for August 2019, in which the RevPAR value corresponded to 66 Euro for hotels in Antalya (Hotel Association of Turkey Tourism Statistics, 2019), with a rate of 62 Euro identified for the sample. The statistical convergence with the general hospitality profile supports the representability of the sample.

\subsection{Descriptive statistics}

The means, standard deviations and correlations between the four variables are presented in Table 1. The results reveal that environmental practices are negatively related to operating costs $(r=-0.267, p<0.05)$, while being positively related to operating revenues $(r=+0.273, p<0.01)$ and profitability $(r=$ $+0.571, p<0.01$ ). The $p$ values between operating performance and financial performance were statistically significant, and the Pearson correlation coefficient value greater than 0.50 confirms the existence of a strong correlation between environmental practices and profitability. 
Table 1 - Descriptive statistics and correlation coefficients

\begin{tabular}{|l|c|c|c|c|}
\hline \multicolumn{1}{|c|}{ Variables } & $\mathbf{1}$ & $\mathbf{2}$ & $\mathbf{3}$ & $\mathbf{4}$ \\
\hline 1. Environmental practices & 1.000 & $-0.267^{*}$ & $+0.273^{* *}$ & $+0.571^{* *}$ \\
\hline 2. Operating costs & $-0.267^{*}$ & 1.000 & -0.087 & $-0.567^{* *}$ \\
\hline 3. Operating reveues & $+0.273^{* *}$ & -0.087 & 1.000 & $+0.464^{* *}$ \\
\hline 4. Profitability & $+0.571^{* *}$ & $-0.567^{* *}$ & $+0.464^{* *}$ & 1.000 \\
\hline Mean & 9.876 & 0.426 & 1.754 & 14.949 \\
\hline Standard deviation & 2.683 & 0.533 & 0.181 & 0.851 \\
\hline
\end{tabular}

${ }^{*} \mathrm{p}<0.05 ;{ }^{* *} \mathrm{p}<0.01$

\subsection{Mediation analyses}

Following the regression-based path analytic framework of the PROCESS procedure, multiple mediation analyses were applied in the present study to assess the relationship between environmental practices and profitability in the lodging industry based on the mediators of operating efficiency and effectiveness. The results of the multiple mediation analysis are presented in Figure 1, in which the direct effect of environmental practices on profitability can be seen to be significant ( $c=0.115$, se=0.025, t=4.549, $p<0.01$ ). When hotels make more extensive environmental applications, profitability tends to increase. It was found that the application of environmental practices has a negative direct effect on operating costs $\left(\mathrm{a}_{1}=-0.053\right.$, se $\left.=0.018, \mathrm{t}=-2.903, \mathrm{p}<0.01\right)$ and $\mathrm{a}$ positive direct effect on operating revenues $\left(a_{2}=0.018\right.$, $\mathrm{se}=0.007, \mathrm{t}=2.693, \mathrm{p}<0.01)$. Both the direct effect of operating costs (measured using the $C / I$ ratio) $\left(b_{1}=-0.705\right.$, se $=0.132$, $t=-5.330, p<0.01)$ and the direct effect of operating revenues (measured using the RevPAR metric) $\left(b_{2}=1.538\right.$, se $=0.351$, $t=4.380, p<0.01$ ) on profitability were found to be significant. Adding the indirect and direct effect of environmental practices on profitability yielded the total effect estimated for the extensiveness of applications in environmental protection. As a result of this, a statistically significant effect was identified for the estimated total effect of environmental practices on profitability based on operating performance $(c=+0.181$, $\mathrm{se}=0.033, \mathrm{t}=+4.417, \mathrm{p}<0.01)$. The total mediated effect of environmental practices (e.g., the value of adjusted R-square) accounted for 33 percent of the variance in financial performance. On the other hand, the value of variance explained by the main effects was 61 percent, and thus an unbiased estimation of the multiple mediation model was concluded to be less than twice as much.

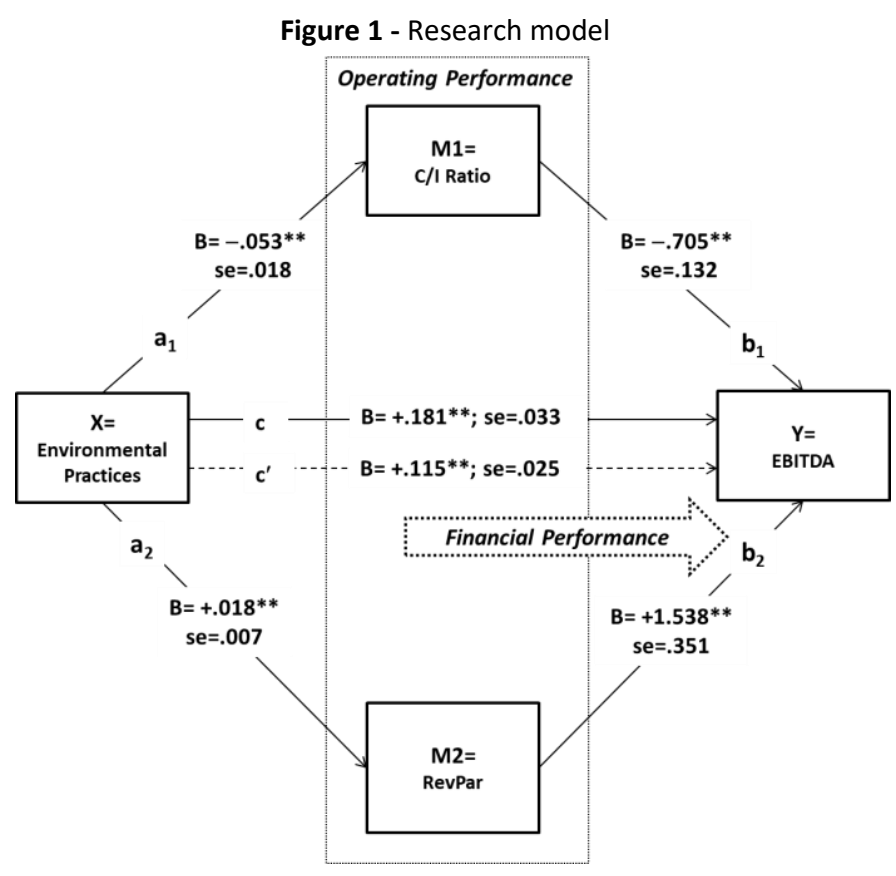

A comparison of the indirect effects of the environmental practices of the hotels on profitability is presented in Table 2. Bootstrap confidence intervals indicate the meaningfulness of indirect effects. If the confidence interval does not include zero between $\mathrm{LL}$ and $\mathrm{UL}$, the indirect effect is inferred to be significant, thus providing support for the mediation effect. As seen in Table 2, the path through a single mediation of operating costs was 95 percent likely to range from +0.013 to +0.070 , and its estimated effect was +0.037 . The indirect effect of operating costs was statistically significant since the 
difference between the two estimates was not equal to zero. Similarly, the bootstrap values for the path through a single mediation of operating revenues ranged from +0.008 to +0.057 at a 95 percent confidence level. The indirect effect of operating revenues, corresponding to the estimated value of +0.028 , was supported for mediation while lying between the confidence intervals that do not include zero. At the same time, the path through both mediators together (point estimate $=+0.066$; Boot se $=+0.017 ; 95 \% \mathrm{BC} \mathrm{Cl}(+0.038,+0.104))$ was found to be significant. In addition to this, the Sobel test, using the normal distribution to derive $p$-values and confidence intervals, produced a $z$-value of 2.52 for the mediated effect of operating costs and a z-value of 2.25 for the mediated effect of operating revenues, confirming further that the mediation is significant. Looking at the indirect effect of environmental practices on financial performance, it can be also compared to the strength of the individual indirect effects against each other. To determine the existence of relative strength in mediation, $\mathrm{Cl}$ values are again examined. In the present study, a single indirect effect contrast was specified by the pairwise distance (operating costs - operating revenues). The value of pairwise contrast (C1), lying between the Cls $(-0.032$ to +0.051$)$, was not significant and, therefore, no difference was found in the strength of the indirect effects.

Table 2 - Confidence intervals for indirect effects

\begin{tabular}{|l|c|c|c|c|}
\hline & \multicolumn{2}{|c|}{ Coefficients } & \multicolumn{2}{c|}{$\begin{array}{c}\text { Bootstrapping 95\% BC } \\
\text { Confidence Interval (CI) }\end{array}$} \\
\hline & Point Estimate & Boot SE & BootLL CI & BootUL CI \\
\hline Effect & & & & +0.104 \\
\hline Total indirect effect of $X$ on $Y$ & +0.066 & +0.017 & +0.038 & +0.070 \\
\hline Indirect effect 1: $X \rightarrow \mathrm{M} 1 \rightarrow Y$ & +0.037 & +0.015 & +0.013 & +0.057 \\
\hline Indirect effect 2: $X \rightarrow \mathrm{M} 2 \rightarrow Y$ & +0.028 & +0.013 & +0.008 & +0.051 \\
\hline C1 & +0.009 & +0.021 & -0.032 & \\
\hline
\end{tabular}

$\mathrm{X}=$ environmental practices, $\mathrm{M} 1=$ operating costs, $\mathrm{M} 2=$ operating revenues, $\mathrm{Y}=$ profitability, $\mathrm{C} 1=$ pairwise contrast: $\mathrm{M} 1-\mathrm{M} 2$

In conclusion, the multiple mediation analysis carried out in the present study indicates that the more hotels participate in environmental practices, the greater the increase in operating profits through cost reduction and revenue enhancement. Overall, these results support the existence of a parallel multiple mediation. When adopting the causal steps approach put forward by Baron and Kenny (Baron \& Kenny, 1986), the pattern observed in the present study is consistent with partial mediation, as the direct effect of environmental practices is statistically significant but smaller than its total effect. On the other hand, the statistical significance of both the total and direct effects is considered to have no influence on an indirect effect in the contemporary mediation analysis approach (Hayes, 2009). According to the contemporary understanding of mediation testing, the statistical non-significance of the total indirect effect would be explicated as no-mediation in any case. Consistent with this, Zhao et al. (2010) identify the three conditions of mediation as follows: (1) indirect-only mediation in cases where the indirect effect is significant, but there is no direct effect, (2) complementary mediation in cases where both the indirect effect and direct effect are significant in the same direction, and (3) competitive mediation in cases where both the indirect effect and direct effects are significant, but in opposite directions. The statistical findings of this study suggest that operating costs and operating revenues serve as complementary mediators in the relationship between environmental practices and hotel profitability.

\section{Conclusion}

The rolling out of an environmental consciousness all over the world is promoting the sustainability management concept for organizations, now more than ever. In parallel with the sustainable growth agenda, recent years have witnessed a noticeable increase in the number of studies of environmental practices in tourism management, although environmental enterprise led to biased results in studies investigating firm profitability. Previous empirical studies have come up with conflicting results due to the short-term observations of green returns, particularly the disregard of indirect effects. Despite the wide variety of benefits, environmental management is not costless from a risk return perspective and may exert a negative or neutral effect over profitability in the short term. On the other hand, a stable profitability-generating effect of environmentalism can be detected even in short-term appraisals in cases where operating performance contributes to the profit buffer in response to return ratios and simultaneously mediates the effect of environmentalism on profitability. Contrary to the risk-return perspective, the theoretical extension of this empirical link fits in with sustainable value creation based on environmental strategies. Environmental management leads to better performance, as it reduces energy and water consumption and the generation of waste therefore increasing resource efficiency. Furthermore, environmentally friendly tourism products and natural and cultural heritage conservation increase guest satisfaction, resulting in revenue growth. The positive impact of environmental management on financial performance occurs more often when businesses benefit from continuous productivity improvement, increased market share and product quality, better corporate reputation, and more satisfied consumers, among many other factors. In other words, environmental sustainability creates performance benefits in internal processes, customer relationships, and 
organizational development dimensions. Sustainability management affects financial results in all of these ways, manifesting in increased revenues and reduced costs. Consistent with the environmental value creation perspective, the study presented here addresses specifically the question of in which ways, and to what extent, does environmentally responsible behavior lead to improved financial performance.
In this direction, the total, direct and indirect causal effects of environmental management practices were tested, and the effect sizes were compared to obtain more consistent results, and the results of the empirical study, based on data collected from 5-star accommodation providers in Antalya, are summarized in Table 3.

Table 3 - Summary of hypotheses

\begin{tabular}{|c|l|c|}
\hline Number & \multicolumn{1}{|c|}{ Hypothesized relationship } & Results \\
\hline $\mathbf{H}_{\mathbf{1}}$ & environmental management practices $\rightarrow$ operating costs $\rightarrow$ profitability & Supported \\
\hline $\mathbf{H}_{\mathbf{2}}$ & environmental management practices $\rightarrow$ operating revenues $\rightarrow$ profitability & Supported \\
\hline $\mathbf{H}_{\mathbf{3}}$ & environmental management practices $\rightarrow$ operating costs and operating revenues $\rightarrow$ profitability & $\begin{array}{c}\text { Supported } \\
\text { (complementary) }\end{array}$ \\
\hline $\mathbf{H}_{\mathbf{4}}$ & differential effects of complement mediators $\rightarrow$ operating costs - operating revenues & Not supported \\
\hline
\end{tabular}

The results confirm the complementary mediating effect of operating performance (i.e., cost savings and revenue generation) in the relationship between environmental practice and short-term profitability, based on the hypotheses derived from the natural resource-based view of environmental behavior. First, supporting hypothesis 1 , this study indicates that operating costs are associated with and mediate the effect of environmental practices on profitability. This result confirms the cost savings effect of environmental management practices on profitability. Second, consistent with hypothesis 2 , the findings of this study also demonstrate that operating revenues are associated with and mediate the effect of environmental practices on profitability. This result confirms the revenuegenerating effect of environmental management practices on profitability. Third, consistent with hypothesis 3 , the data shows that operating costs and operating revenues work together to improve green profits. Fourth, as regards hypothesis 4 comparing the relative strength of the mediating effects, the findings reveal a very similar impact of operating performance mediators over hotel profitability. There is no difference between the effects of complementary operating performance parameters in increasing profitability in environmentally friendly management. As can be concluded from the results, part of environmentalism's profit-enhancing effect depends on operating performance, and this effect is evenly distributed between cost reduction and revenue generation in the Turkish lodging sector context. A lack of difference in the effect size of operating costs and operating revenues in enhancing green profitability tends to prevail in destinations implementing ecoactivities reactively. The more proactivity green practices are pursued, the greater the revenue generation effect of environmentalism on profitability. When compared with cost reduction or risk aversion, the revenue generated through environmentalism may vary from culture to culture and may differ greatly between different levels of sustainable development. Overall, this study expands upon previous literature in arguing that environmental hotel practices increase profitability in the short term. More importantly, this study makes a theoretical reconciliation of apparently conflicting empirical findings by revealing the complementary mediating role of costs reduction and revenue generation in the relationship between environmentalism and profitability. The study contributes further to the literature by addressing the question of whether the environmental management strategy applied by hotels leads to greater revenue growth rather than cost savings, or vice versa.

The study has some implications for hotel management. Hotels employ environmental management practices to reduce costs and increase revenues that include the use of energy-saving LED bulbs, the adoption of modern cleaning equipment technologies, the use of energy management systems for boiler fuels, the use of efficient and less energy-consuming systems in cooling groups, the use of solar water heating systems, the use of energy-saving card systems in rooms and the installation of systems that disable air conditioners, all of which contribute to the environment through lower consumption and emissions, while also reducing costs. As an environmentally friendly behavior, notices are placed in guest rooms asking for help in the reduction of laundry, which contributes to the natural environment by reducing water consumption, electricity consumption, and the release of toxic chemicals into the environment, while at the same time significantly reducing laundry costs. Along with these environmentally sensitive practices, environmentally related awards and certificates (e.g., ISO 14001, Blue Flag, Green Star) exhibited in the common areas of the hotels serve to improve customer perception. Finally, managerial practices related to the disposal, recycling, and reuse of waste products both provide cost advantages and contribute to corporate reputation. While all these practices positively affect profitability by reducing costs, they may also significantly increase revenues over through the good reputation gained on the customer side. As supported in the present study, operating performance is better placed to increase profitability than reductions in costs. If hotels expect high profits through environmental management, they should invest in more proactive and revenue-generating activities in the specific field.

The knowledge generated by the present study is limited to the operating ratios in accounting performance - the other side 
representing the ability of an organization to generate returns for its shareholders (e.g., accounting ratios of return). Return ratios should be accessed to gain more forward-looking data that represents the real value of investments. However, in volatile markets, the potential exposure to systemic risks from the unexpected and actual returns on an investment is extremely high. Due to the fragile nature of Turkish tourism, hotels in Antalya rarely include return calculations in their internal reports. As the shareholding structure is almost nonexistent, there is hence no need for concern regarding the voting rights of different shareholders. Furthermore, debt capital is used only to get a good credit rating and the necessary accreditation from banks, rather than for future dividends to suppliers of equity. Accordingly, in the present study, there was an obligation to exclude green investment returns from the conditional effects of environmental performance. Future studies should address the question of to what extent the different investment instruments dedicated to environmental activities influence the profit bottom. The multiple mediating effects of the operating and return ratios should be analyzed together to determine hotel profitability, for which a longitudinal design approach will be beneficial. Finally, environmental practices and their underlying rationalities are context-dependent. So future studies should investigate the impact of the institutional environment on the relationship between environmental management and profitability.

\section{References}

Albertini, E. (2013). Does environmental management improve financial performance? A meta-analytical review. Organization \& Environment, 26(4), 431-457. https://doi.org/10.1177/1086026613510301

Alshehhi, A., Nobanee, H., \& Khare, N. (2018). The impact of sustainability practices on corporate financial performance: Literature trends and future research potential. Sustainability, 10(2), 494. https://doi.org/10.3390/su10020494

Alvarez-Gil, M. J., Burgos-Jimenez, J., \& Cespedes-Lorente, J. J. (2001). An analysis of environmental management, organizational context and performance of Spanish hotels. Omega, 29(6), 457-471. https://doi.org/10.1016/S0305-0483(01)00033-0

Assaf, A. G., Josiassen, A., \& Cvelbar, L. K. (2012). Does triple bottom line reporting improve hotel performance? International Journal of Hospitality Management, 31(2), 596-600. https://doi.org/10.1016/j.ijhm.2011.08.005

Armitage, P., \& Berry, G. (1994). Bayes' theorem. In P. Armitage, \& G. Berry (3rd Ed.). Statistical methods in medical research (pp. 71-77). Oxford: Blackwell.

Bagur-Femenias, L., Marti, J., \& Rocafort, A. (2015). Impact of sustainable management policies on tourism companies' performance: the case of the metropolitan region of Madrid. Current Issues in Tourism, 18(4), 376-390. https://doi.org/10.1080/13683500.2014.932757

Baron, R. M., \& Kenny, D. A. (1986). The moderator-mediator variable distinction in social psychological research: Conceptual, strategic, and statistical considerations. Journal of Personality and Social Psychology, 51(6), 1173-1182.

Bohdanowicz, P. (2006). Environmental awareness and initiatives in the Swedish and Polish hotel industries-survey results. International Journal of Hospitality Management, 25(4), 662-682. https://doi.org/10.1016/j.ijhm.2005.06.006
Bramwell, B., \& Alletorp, L. (2001). Attitudes in the Danish tourism industry to the roles of business and government in sustainable tourism. International Journal of Tourism Research, 3(2), 91-103. https://doi.org/10.1002/jtr.242

Branco, M. C., \& Rodrigues, L. L. (2006). Corporate social responsibility and resource-based perspectives. Journal of Business Ethics, 69(2), 111132. https://doi.org/10.1007/s10551-006-9071-z

Carmona-Moreno, E., Céspedes-Lorente, J., \& De Burgos-Jiménez, J. (2004). Environmental strategies in Spanish hotels: contextual factors and performance. The Service Industries Journal, 24(3), 101-130. https://doi.org/10.1080/0264206042000247786

Cerchione, R., \& Harbhajan, B. (2020). Measuring the impact of sustainability policy and practices in tourism and hospitality industry. Business Strategy and the Environment, 29(3), 1109-1126. https://doi.org/10.1002/bse.2420

Child, J. W., \& Marcoux, A. M. (1999). Freeman and Evan: Stakeholder theory in the original position. Business Ethics Quarterly, 9(2), 207-223. https://doi.org/10.2307/3857472

Claver-Cortés, E., Molina-Azorin, J. F., Pereira-Moliner, J., \& LópezGamero, M. D. (2007). Environmental strategies and their impact on hotel performance. Journal of Sustainable Tourism, 15(6), 663-679. https://doi.org/10.2167/jost640.0

Climate Accountability Institute. (2017). CDP carbon majors report 2017, The carbon majors database. Retrieved from https://climateaccountability.org/carbonmajors.html

Cordeiro, J. J., \& Sarkis, J. (1997). Environmental proactivism and firm performance: evidence from security analyst earnings forecasts. Business Strategy and the Environment, 6(2), 104-114. https://doi.org/10.1002/(SICI)1099-0836(199705)6:2<104::AIDBSE102>3.0.CO;2-T

Cvelbar, L. K., \& Dwyer, L. (2013). An importance-performance analysis of sustainability factors for long-term strategy planning in Slovenian hotels. Journal of Sustainable Tourism, 21(3), 487-504. https://doi.org/10.1080/09669582.2012.713965

Dascalu, C., Caraiani, C., Lungu, C. I., Colceag, F., \& Guse, G. R. (2010). The externalities in social environmental accounting. International Journal of Accounting \& Information Management, 18(1), 19-30. https://doi.org/10.1108/18347641011023252

Dastgeer, G., ur Rehman, A., \& Asghar, M. A. (2020). Selection and use of mediation testing methods; application in management sciences. Business \& Economic Review, 12(3), 1-48. dx.doi.org/10.22547/BER/12.3.1

de Grosbois, D. (2012). Corporate social responsibility reporting by the global hotel industry: Commitment, initiatives and performance. International Journal of Hospitality Management, 31(3), 896-905. https://doi.org/10.1016/j.ijhm.2011.10.008

Deephouse, D. L., \& Carter, S. M. (2005). An examination of differences between organizational legitimacy and organizational reputation. Journal of Management Studies, 42(2), 329-360. https://doi.org/10.1111/j.1467-6486.2005.00499.x

Dixon-Fowler, H. R., Slater, D. J., Johnson, J. L., Ellstrand, A. E., \& Romi, A. M. (2013). Beyond does it pay to be green? A meta-analysis of moderators of the CEP-CFP relationship. Journal of Business Ethics, 112(2), 353-366. https://doi.org/10.1007/s10551

Donleavy, G. (2010). An introduction to accounting theory. Retrieved from http://thuvienso.bvu.edu.vn/handle/TVDHBRVT/15068

Dwyer, L. (2005). Relevance of triple bottom line reporting to achievement of sustainable tourism: A scoping study. Tourism Review International, 9(1), 79-938. https://doi.org/10.3727/154427205774791726

Elkington, J. (1998). Partnerships from cannibals with forks: The triple bottom line of 21st-century business. Environmental Quality Management, 8(1), 37-51. https://doi.org/10.1002/tqem.3310080106 Endrikat, J., Guenther, E., \& Hoppe, H. (2014). Making sense of conflicting empirical findings: A meta-analytic review of the relationship between corporate environmental and financial performance. 

$\begin{aligned} & \text { European Management Journal, 32(5), 735-751. } \\ & \text { https://doi.org/10.1016/j.emj.2013.12.004 }\end{aligned}$

Fauzi, H., Svensson, G., \& Rahman, A. A. (2010). Triple bottom line as sustainable corporate performance: A proposition for the future. Sustainability, 2(5), 1345-1360. http://dx.doi.org/10.3390/su2051345

Fotiadis, A. K., Vassiliadis, C. A., \& Rekleitis, P. D. (2013). Constraints and benefits of sustainable development: A case study based on the perceptions of small-hotel entrepreneurs in Greece. Anatolia, 24(2), 144-161. https://doi.org/10.1080/13032917.2012.741049

Freeman, R. E., Harrison, J. S., Wicks, A.C., Parmar, B. L., \& De Colle, S. (2010). Stakeholder theory: the state of the art. Cambridge: Cambridge University Press.

Friedman, M. (2007). The social responsibility of business is to increase its profits. In W.C. Zimmerli, M. Holzinger, \& K. Richter (Ed). Corporate ethics and corporate governance (pp. 173-178). Berlin: Springer.

Frondel, M., Horbach, J., \& Rennings, K. (2007). End-of-pipe or cleaner production? An empirical comparison of environmental innovation decisions across OECD countries. Business Strategy and the Environment, 16(8), 571-584. https://doi.org/10.1002/bse.496

Garay, L., \& Font, X. (2012). Doing good to do well? Corporate social responsibility reasons, practices and impacts in small and medium accommodation enterprises. International Journal of Hospitality Management, $31(2)$,

https://doi.org/10.1016/j.ijhm.2011.04.013

329-337.

Ghaderi, Z., Mirzapour, M., Henderson, J. C., \& Richardson, S. (2019). Corporate social responsibility and hotel performance: A view from Tehran, Iran. Tourism Management Perspectives, 29, 41-47. https://doi.org/10.1016/j.tmp.2018.10.007

Gil, M. A., Jiménez, J. B., \& Lorente, J. C. (2001). An analysis of environmental management, organizational context and performance of Spanish hotels. Omega, 29(6), 457-471. https://doi.org/10.1016/S0305-0483(01)00033-0

Gilley, K. M., Worrell, D. L., Davidson III, W. N., \& El-Jelly, A. (2000). Corporate environmental initiatives and anticipated firm performance: the differential effects of process-driven versus product-driven greening initiatives. Journal of Management, 26(6), 1199-1216. https://doi.org/10.1177/014920630002600607

Gimenez, C., Sierra, V., \& Rodon, J. (2012). Sustainable operations: Their impact on the triple bottom line. International Journal of Production Economics, 140(1), 149-159. https://doi.org/10.1016/j.ijpe.2012.01.035

Hart, S. L. (1995). A natural-resource-based view of the firm. Academy of Management Review, 20(4), 986-1014. https://doi.org/10.5465/amr.1995.9512280033

Hart, S. L., \& Ahuja, G. (1996). Does it pay to be green? An empirical examination of the relationship between emission reduction and firm performance. Business Strategy and the Environment, 5(1), 30-37. https://doi.org/10.1002/(SICI)1099-0836(199603)5:1<30::AIDBSE38>3.0.CO;2-Q

Hart, S. L., \& Dowell, G. (2011). Invited editorial: A natural-resourcebased view of the firm: Fifteen years after. Journal of Management, 37(5), 1464-1479. https://doi.org/10.1177/0149206310390219

Hassel, L., Nilsson, H., \& Nyquist, S. (2005) The value relevance of environmental performance. European Accounting Review, 14(1), 4161. https://doi.org/10.1080/0963818042000279722

Hayes, A. F. (2009). Beyond Baron and Kenny: Statistical mediation analysis in the new millennium. Communication Monographs, 76(4), 408-420. https://doi.org/10.1080/03637750903310360

Hayes, A. F. (2017). Introduction to Mediation, Moderation, and Conditional Process Analysis: A Regression-Based Approach. New York: Guilford publications.

Helfert, E.A. (2003). Techniques of Financial Analysis: A Guide to Value Creation; New York: McGraw-Hill.

Hillery, M., Nancarrow, B., Griffin, G., \& Syme, G. (2001). Tourist perception of environmental impact. Annals of Tourism Research, 28(4), 853-867. https://doi.org/10.1016/S0160-7383(01)00004-4
Hirth, S., \& Uhrig-Homburg, M. (2010). Investment timing, liquidity, and agency costs of debt. Journal of Corporate Finance, 16(2), 243-258. https://doi.org/10.1016/j.jcorpfin.2010.01.002

Hotel Association of Turkey Tourism Statistics. (2019). STR report. Retrieved from www.turob.com

Inoue, Y., \& Lee, S. (2011). Effects of different dimensions of corporate social responsibility on corporate financial performance in tourismrelated industries. Tourism Management, 32(4), 790-804. https://doi.org/10.1016/j.tourman.2010.06.019

Jones, P., Hillier, D., \& Comfort, D. (2014). Sustainability in the global hotel industry. International Journal of Contemporary Hospitality Management, 26(1), 5-17. https://doi.org/10.1108/IJCHM-10-20120180

Kang, K. H., Lee, S., \& Huh, C. (2010). Impacts of positive and negative corporate social responsibility activities on company performance in the hospitality industry, International Journal of Hospitality Management, 29(1),

https://doi.org/10.1016/j.ijhm.2009.05.006

Kasim, A. (2009). Managerial attitudes towards environmental management among small and medium hotels in Kuala Lumpur. Journal of Sustainable Tourism, 17(6), 709-725. https://doi.org/10.1080/09669580902928468

Kassinis, G. I., \& Soteriou, A. C. (2003). Greening the service profit chain: The impact of environmental management practices. Production and Operations Management, 12(3), 386-403. https://doi.org/10.1111/j.1937-5956.2003.tb00210.x

Klassen, R. D., \& McLaughlin, C. P. (1996). The impact of environmental management on firm performance. Management Science, 42(8), 11991214. https://doi.org/10.1287/mnsc.42.8.1199

Le, Y., Hollenhorst, S., Harris, C., McLaughlin, W., \& Shook, S. (2006). Environmental management: A study of Vietnamese hotels. Annals of $\begin{array}{llll}\text { Tourism } \quad \text { Research, 33(2), 545-567. } & \end{array}$ https://doi.org/10.1016/j.annals.2006.01.002

Levy, S. E., \& Park, S. Y. (2011). An analysis of CSR activities in the lodging industry. Journal of Hospitality and Tourism Management, 18(1), 147154. https://doi.org/10.1375/jhtm.18.1.147

Lomborg, B. (2003). The Skeptical Environmentalist: Measuring the Real State of the World. Cambridge: Cambridge University Press.

López-Gamero, M. D., Molina-Azorín, J. F., \& Claver-Cortés, E. (2009). The whole relationship between environmental variables and firm performance: Competitive advantage and firm resources as mediator variables. Journal of Environmental Management, 90(10), 3110-3121. https://doi.org/10.1016/j.jenvman.2009.05.007

Lucas, M. T., \& Wilson, M. A. (2008). Tracking the relationship between environmental management and financial performance in the service industry. Service Business, 2(3), 203-218. https://doi.org/10.1007/s11628-008-0035-5

Manderson, A. K. (2006). A systems based framework to examine the multi-contextural application of the sustainability concept. Environment, Development and Sustainability, 8(1), 85-97. https://doi.org/10.1007/s10668-005-2787-6

Mensah, I. (2006). Environmental management practices among hotels in the greater Accra region. International Journal of Hospitality Management, 25(3), 414-431. https://doi.org/10.1016/j.ijhm.2005.02.003

Middleton, A. (2015). Value relevance of firms' integral environmental performance: evidence from Russia. Journal of Accounting and Public Policy, 34(2), 204-211. https://doi.org/10.1016/j.jaccpubpol.2014.12.001

Mihalič, T. (2016). Sustainable-responsible tourism discourse -towards responsustable tourism. Journal of Cleaner Production, 111(Part B), 461-470. https://doi.org/10.1016/j.jclepro.2014.12.062

Mihalič, T. A. (2013). A green tourism barometer in the time of economic crisis-the concept and case of Slovenia. Proceedings of 2nd International Scientific Conference Tourism in South East Europe, Croatia. https://ssrn.com/abstract=2289243 
Mihalič, T., Žabkar, V., \& Cvelbar, L. K. (2012). A hotel sustainability business model: evidence from Slovenia. Journal of Sustainable Tourism 20(5),

701-719. https://doi.org/10.1080/09669582.2011.632092

Miralles-Quirós, M. M., Miralles-Quirós, J. L., \& Valente Gonçalves, L. M. (2018). The value relevance of environmental, social, and governance performance: the Brazilian case. Sustainability, 10(3), 574. https://doi.org/10.3390/su10030574

Mishra, S., \& Suar, D. (2010). Does corporate social responsibility influence firm performance of Indian companies? Journal of Business Ethics, 95(4), 571-601. https://doi.org/10.1007/s10551-010-0441-1

Nawrocka, D., \& Parker, T. (2009). Finding the connection: environmental management systems and environmental performance. Journal of Cleaner Production, 17(6), 601-607. https://doi.org/10.1016/j.jclepro.2008.10.003

Porter, M. E., \& Van der Linde, C. (1995). Toward a new conception of the environment-competitiveness relationship. Journal of Economic Perspectives, 9(4), 97-118. https://doi.org/10.1257/jep.9.4.97

Republic of Turkey Ministry of Culture and Tourism. (2017). Hotel statistics. Retrieved from https://www.ktb.gov.tr/?_dil=2

Republic of Turkey Ministry of Culture and Tourism. (2019). Destinations. Retrieved from https://www.ktb.gov.tr/?_dil=2

Rodríguez, F. J. G., \& Cruz, Y. D. M. A. (2007). Relation between socialenvironmental responsibility and performance in hotel firms. International Journal of Hospitality Management, 26(4), 824-839. https://doi.org/10.1016/j.ijhm.2006.08.003

Salzmann, O., lonescu-Somers, A., \& Steger, U. (2005). The business case for corporate sustainability: literature review and research options. European Management Journal, 23(1), 27-36. https://doi.org/10.1016/j.emj.2004.12.007

Segarra-Oña, M. D. V., Peiró-Signes, Á., Verma, R., \& Miret-Pastor, L. (2012). Does environmental certification help the economic performance of hotels? Evidence from the Spanish hotel industry. Cornell Hospitality Quarterly, 53(3), 242-256. https://doi.org/10.1177/1938965512446417

Semenova, N., Hassel, L. G., Nilsson, H. (2010). The Value Relevance of Environmental and Social Performance: Evidence from Swedish SIX 300 Companies. Liiketaloudellinen Aikakauskirja, 3(10), 265-292.

Singal, M. (2014). The link between firm financial performance and investment in sustainability initiatives. Cornell Hospitality Quarterly, 55(1), 19-30. https://doi.org/10.1177/1938965513505700

Stylos, N., \& Vassiliadis, C. (2015). Differences in sustainable management between four-and five-star hotels regarding the perceptions of three-pillar sustainability. Journal of Hospitality $\begin{array}{llll}\text { Marketing \& } \quad \text { Management, 24(8), 791-825. } & \text {. }\end{array}$ https://doi.org/10.1080/19368623.2015.955622

Toms, J. S. (2002). Firm resources, quality signals and the determinants of corporate environmental reputation: some UK evidence, British Accounting Review, 34(3), 257-282. https://doi.org/10.1006/bare.2002.0211

Trung, D. N., \& Kumar, S. (2005). Resource use and waste management in Vietnam hotel industry. Journal of Cleaner Production,13(2), 109-116. https://doi.org/10.1016/j.jclepro.2003.12.014

Tufano, P. (1998). Agency costs of corporate risk management. Financial Management, 27(1), 67-77. https://doi.org/10.2307/3666152

TUI Group. (2019). Responsibility. Retrieved from www.tuisustainability.com

Walley, N., \& Whitehead, B. (1994). It's not easy being green. Harvard Business Review, 72(3), 46-52. https://doi.org/10.4236/jmmce.2012.114028

Whitley, B. E., \& Kite, M. E. (2013). Principles of research in behavioral science. Abingdon, UK: Routledge.

Wood, D. J., \& Jones, R. E. (1995). Stakeholder mismatching: A theoretical problem in empirical research on corporate social performance. The International Journal of Organizational Analysis, 3(3), 229-267. https://doi.org/10.1108/eb028831

Zhang, J. J., Joglekar, N. R., \& Verma, R. (2012). Exploring resource efficiency benchmarks for environmental sustainability in hotels. Cornell Hospitality Quarterly, 53(3), 229-241. https://doi.org/10.1177/1938965512441165

Zhao, X., Lynch Jr, J. G., \& Chen, Q. (2010). Reconsidering Baron and Kenny: myths and truths about mediation analysis. Journal of Consumer Research, 37(2), 197-206. https://doi.org/10.1086/651257 